\title{
Study on the Issue of Staff Training in Business Hotel
}

\author{
Qiumei Fan \\ Tourism and Geography Science School, Shenyang University \\ Shenyang 110041, China \\ E-mail: fanqmsy@163.com
}

\begin{abstract}
According to the analysis of characteristics of hotel business and business traveler, a business hotel will have new requirements to employees. So this essay puts forward new ways of staff training in business hotels.

Keywords: Business hotel, Staff, Training, Ways

Along with the speeding of the social development and the information-based progress, the modern science and technology gradually gets into a hotel industry, so that, the degree of hotel intelligence is running higher, and the guest feels more comfortable and convenient. Reservation and promotion on the net gradually replace traditional ways with telephone and mails. Guests can choose the rooms he likes from the computer directly. The guest's identity data will also be recorded into a computer with scanners and avoid artificial register and confirm. The guest room provides with the VCD facilities, multi-media Internet and electronics to show and confirm his own personality service contents, such as: morning calls, dressing hours and schedule to ticket and dinner party, business consultant, the tour reservation, secretary service, etc..
\end{abstract}

\section{Characteristics of Business travelers}

Business travelers are not ordinary travelers. The major purpose of taking a tour is for the business or other public services, not only for leisure. Most of them are high-level white-collars with high education, high income level and rich travel experience. Their overall travel demand is convenient, fast and efficient.

Business travelers are strongly independent and not be dominative. They treat the hotel as an information and services provider. So hotels have to provide them with products in diversity, personalization and flexibility. Business guests pursuit an easy, comfortable relaxation after the business affairs.

Business travelers usually stay 2-3 days in hotel. Because they are generally highly educated entrepreneurial elites with international communication skills and rich experience in business management, the hotel staff's service attitude, language and communication skills have to show a high degree of courtesy and politeness.

\section{Business characteristics of Business Hotels and requirements of the employees' qualities}

A business hotel is the hotel that provides accommodation, meals, business activities and related facilities to business travelers who are engaged in business activities.

The most important feature of the hotel business is to have higher degree of returning customers. Therefore, the hotel's services items, qualities, and standards have to facilitate business travelers. Hotel facilities will be comfortable, convenient and safe. Hotels will consider and provide a number of facilities and communication systems for business travelers.

According to the analysis of characteristics of hotel business and business traveler, a business hotel will have new requirements to employees. Business hotels should train a group of skilled staffs with fluent foreign languages skills, good etiquette and courtesy to provide business travelers with quick meal and a small banquet service because business travelers often arrange a more in-depth business negotiation on the table.

Modern business travel is coming from the development of modern political, economic, scientific and technological, cultural, educational activities which requires the organizers of business travel should have good professional knowledge and skills, as well as a broad range of knowledge to master the latest information and to track changes in the market. It also requires business hotel reception service to be superb and accurate, or it will not only affect the business activities of business travelers, but also will damage the reputation of the hotel itself. Therefore, it is the top priorities for a business hotel to strengthen the trainings for their staffs and make them not only knows about tourism business, but also master the business activities. 


\section{Ways of hotel staff training}

The basic requirements for the staffs in the hotel industry can be summed up as ASKH: Attitude, Skills, Knowledge and Habit. Attitude means not only is "dedicated" to jobs but also is the love of lives and having positive, optimistic, and cheerful qualities. Skills refer to technical and service skills. Knowledge must be latest and comprehensive. Habit means that staffs will develop good habits in every aspect when getting along with others.

To build a high-quality workforce to meet the needs of modern business travel, hotel should be training staffs in the following aspects:

\subsection{Knowledge training}

Some people say that the tourism industry is labor-intensive industry, emotion-intensive industry, and intelligence-intensive industry because it needs people with extensive knowledge and wisdom smart.

\subsubsection{E-commerce training}

Hotel should hold a variety of computers, office automation knowledge lectures combining training and assessment.

\subsubsection{Foreign language training}

We need to hire for foreign language teachers to strengthen communicating with business guests. Types of Language have to be wide, but not too deep to understand, especially in the hotel common language and vocabulary.

\subsubsection{Business skills training}

To provide accurate and efficient service is our overall objective in hotels. Business customers, in particular the overseas Chinese and the Japanese, pay attention to efficiency and have a high degree of requirement of service quality because they believe time is money. Through business skills trainings, we can develop quality of care and flexible adaptability. In addition, business skills training include etiquette and manners training, etc.

\subsection{Training on attitude}

The reason why some people can not manage the business well is not because they do not have necessary knowledge, is because they do not have right attitude. And it is the same to some companies. Training, mainly make leaders in hotels change their attitudes to adapt to social development.

\subsection{Training on the ways of thinking}

Some people are not in shortage of knowledge, but lag of ways of thinking and lack of creative thinking skills. Some Chinese people gave lectures in U.S. before. During the lectures, some Americans said they did not want to listen anymore because they believe the lecturer's thing has been behind about 30 years than that of Americans'. Therefore, the way of thinking is an important content of the training.

\subsection{Finding the feelings}

That is the method of going out while coming back. Some Japanese business communities organize companies to study abroad, and do some researches on resource advantages of local destination, customs, local customers' buying preferences, and so on, so that entrepreneurs can find the feelings to sell goods internationally. In this way, it will help entrepreneurs to open up the market and win profits.

In the era of knowledge economy, there is an increasing demand on qualities of business hotels staffs. Hotels must pay close attention to staff training, and strive to create a large number of high-quality knowledge workers to adapt to the requirements of knowledge management.

\section{References}

Chen, Ying. (2004). New model of training in modern hotels. Human Resource Development, 8: 43-44.

Hong, Tao. (2005). On the hotel industry staff training. Coastal Business and Technology, 7:187-188.

Wang, Hua. (2005). Analysis on staff training in star hotels in Guilin city. Journal of Guilin College, 16(4):41-43.

$\mathrm{Xu}$, Wenyuan. (2004). Rethinking to hotel training. Enterprise economy, 4:139-140. 